\title{
Disciplining Techniques Used by Teachers and Principals to Deal with Students' Incivilities in Eritrean Schools
}

\author{
Zecarias Zemichael* Zersenay Habte Frezghi Tekle Habtemariam Andemeskel \\ Samson Kiflay Senait Fikadu
}

\begin{abstract}
In the Eritrean school system, corporal punishment is officially banned, but teachers and principals are often observed using it. There is lack of empirical evidence about the disciplining techniques employed by teachers and school administrators in the literature representing the Eritrean context. However, students and parents complain about the way teachers and school leadership attempt to discipline students. The paper explored the repertoires of strategies schools employ to handle students' misbehaviors and alternative mechanisms of disciplining to positively influence misbehaving students. The study used cross-sectional survey research method combining qualitative and quantitative research approaches. The study involved 513 participants comprising school management team, teachers, students, members of parent-teacher association, school discipline committee from five schools and college graduating students. Therefore, qualitative and quantitative data were collected from multiple sources of information through questionnaire, interview and focus group discussions. In addition, experiential data were gathered in a field work of school based observation and relevant secondary data. The results are thematically presented following the major research questions. The main "disciplining techniques teachers and school principals use in school compounds are discussed in detail. The findings show that the disciplining techniques employed in the schools are corporal punishments that reflect the teachers' and principals' aggression rather than wisely guiding and disciplining misbehaving students.
\end{abstract}

Keywords: corporal punishment, disciplining techniques, positive disciplining strategies

DOI: $10.7176 / \mathrm{JEP} / 12-4-01$

Publication date: February $28^{\text {th }} 2021$

\section{Introduction}

Students' discipline in schools is a function of affect, behavior, cognition and socially constructed as well as personal values. Behavioral, cognitive and constructive approaches are pillars in understanding and shaping human behavior/thought and empowering people to whole-heartedly behave in desirable ways (Llywodraeth Cymru, Welsh Government, 2012). These approaches coherently combine the issues of students' discipline from the students themselves and environmental perspectives. Behaviorists focus on the role of reward, punishment and consequences in shaping behavior. The cognitive strategies focus on the significance of understanding the mindset, thought patterns and short-term and long-term motives of learners that presumed to precede the misbehaviors and proactive strategies that "lead to positive behavior and development of self-confidence" (Sunday-Piaro, 2018, p. 944). This is because teachers and principals need to fully understand the misbehaving learners' thoughts and motives (Marciniak, 2015).

The constructivist approach in education is an integral part of students' disciplining mechanism in schools. Constructivists believe that knowledge is socially constructed and students' discipline is social, cultural and moral issue. The renowned Russian psychologist, Lev Vygotsky, emphasizes and amplifies the role of elders and other guides in shaping the learners' orientation. Such theoretical frameworks of students' disciplining strategies promote the teachers' and principals' position to holistic understanding of their students' behaviors and foster positive classroom environment (Walters \& Frei, 2007). Therefore, disciplining students is significantly important for "instilling a sense of responsibility and maturity in the students" (ibid).

The issue of "disciplining" young children is a major issue in Eritrean families. Sometimes the parental act of disciplining a child is so strict that focuses on morality, ethics and norms in the communities but gravely harms the rights and human dignity of the child. Strict disciplining and corporal punishment practices can physically and psychologically hurt the young. This paper examined the disciplining techniques used by teachers and school leaders in disciplining misbehaving students in Eritrean schools. School discipline refers to the codes and principles teachers and principals practice to guide and constructively shape the conduct of misbehaving students. Students' discipline in the school context denotes to the act of guiding students on how to behave in a desirable way. It is a process of guiding learners to promote their educational, social, emotional, moral and ethical developments to enable the students to live and grow responsibly. Thus, school discipline in this research is defined the same way as Ekamen \& Edet (2013, p.19) contended "a systematic instruction given to students" to guide them to behave in a desirable way in the school.

In the Eritrean education system, the students' code of conduct is vaguely stated and assessed; school rule are not clearly communicated to students. However, every student's conduct is graded and reported every semester in the academic certificate of the learner. The school disciplinary rules set by the Ministry of Education 
(MoE), Eritrea, mainly focus on telling the students about the school "dos and don'ts." The MoE (1997) set rules and regulations regarding students' discipline in schools. The working document of the Ministry lists what it call the "30 golden rules" that stipulate what is expected of the students as desirable behavior in school. The rules are simply advisements for students rather than certain rules pertaining to specific disciplinary problems.

Generally, corporal punishment in schools is not officially allowed by the MoE (1997). The document of guidelines clearly indicated that "under any circumstance, no teacher or school leader is allowed to insult, affront or use corporal punishment to discipline students." Although corporal punishment is officially banned in the Eritrean school system, teachers and school management team members are often observed using corporal punishment mainly on the pretext of 'disciplining misbehaving students.' There is lack of empirical evidence about the disciplining techniques employed by teachers and school administrators in the literature representing the Eritrean context. However, students and parents complain about the way teachers and school leadership attempt to discipline misbehaving students.

The paper explored the repertoires of strategies teachers and school leaders employ to handle students' misbehaviors. It further examined the disciplinary practices in schools in light of the Eritrean school rules and regulations. The study searched for alternative mechanisms schools use to positively influence the misbehaving students. Thus, the two major research questions of the study were "what are the common disciplining techniques practiced by teachers and principals?' and 'what alternative practices can be used as positive disciplinary measures in the schools?'

\section{Research Method}

The study was conducted in five school of central region, Eritrea, using cross-sectional survey research method combining qualitative and quantitative research approaches. The research surveyed the ways of disciplining misbehaving students practiced by teachers and school leadership. The study involved 513 participants from the school community members namely school administrators, teachers and students. School management team, PTA, school discipline committee from five schools and college graduating students were involved.

Therefore, the data were collected from multiple sources of information to answer the major research questions of the study. The quantitative data were collected using 5-point Likert-type scale questionnaire and the qualitative data were gathered using focus group discussions (FGDs) guiding questions as data collection tools. Thus, 470 questionnaires were distributed for 67 teachers and 403 students. On the other hand, 43 participants took part through FGDs in 7 groups to assess the disciplining techniques and alternative positive disciplinary strategies in the schools. Experiential data were gathered through field work observation in school and desk top review of relevant data. With regard to the data analysis techniques, the quantitative data are analyzed using relevant descriptive techniques and the qualitative data are qualitatively summarized. The results of the FGDs, open-ended question responses and observations are thematically presented following the major research questions.

\section{Results}

The following bar charts, photos and tables summarize the quantitative and qualitative results of the study. The photos are disguised to protect the privacy of the actors. The observation data and descriptive results of the teachers' and students' responses show that teachers and principals highly apply corporal punishment and discomforting techniques "to discipline" misbehaving students. The teachers and principals also temporary confiscate students' belongings, consult parent/guardian, fine and academically suspend the students.

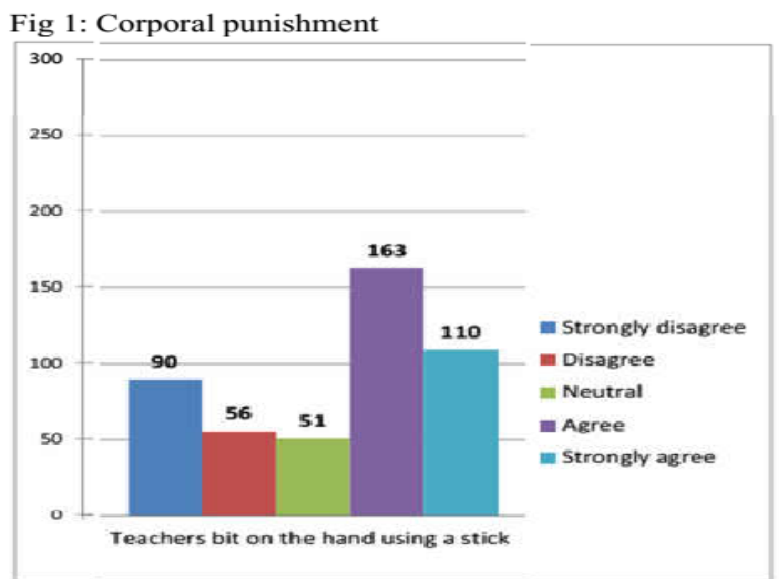

Fig 2: Counselor's professional support

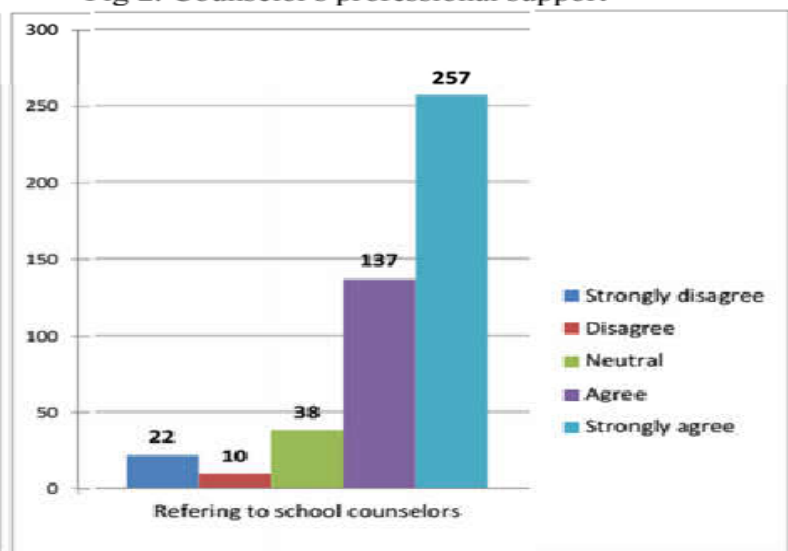

The Likert-type scale responses are descriptively presented in the descriptive results of the analyses are described here. The bars indicate the responses to the statements that "teachers bit students on the hand using a 
stick" (left) and the "need for the practice of referring misbehaving students to school based counseling office" as an alternative mechanism of disciplining in the schools (right). Despite corporal punishment is not allowed, majority of the respondents agreed that teachers bit students using a stick. The participants strongly agree on the need to appropriately refer misbehaving students to a school counselor as an alternative to corporal punishment. The results portray the descriptive results of teachers and students views on the significance of positive disciplining techniques that must be used by teachers and principals in the schools. However, they clearly noted that there are no functional counseling offices providing supportive guidance and counseling services to students in the schools.

Fig. 3: Improper hair cutting

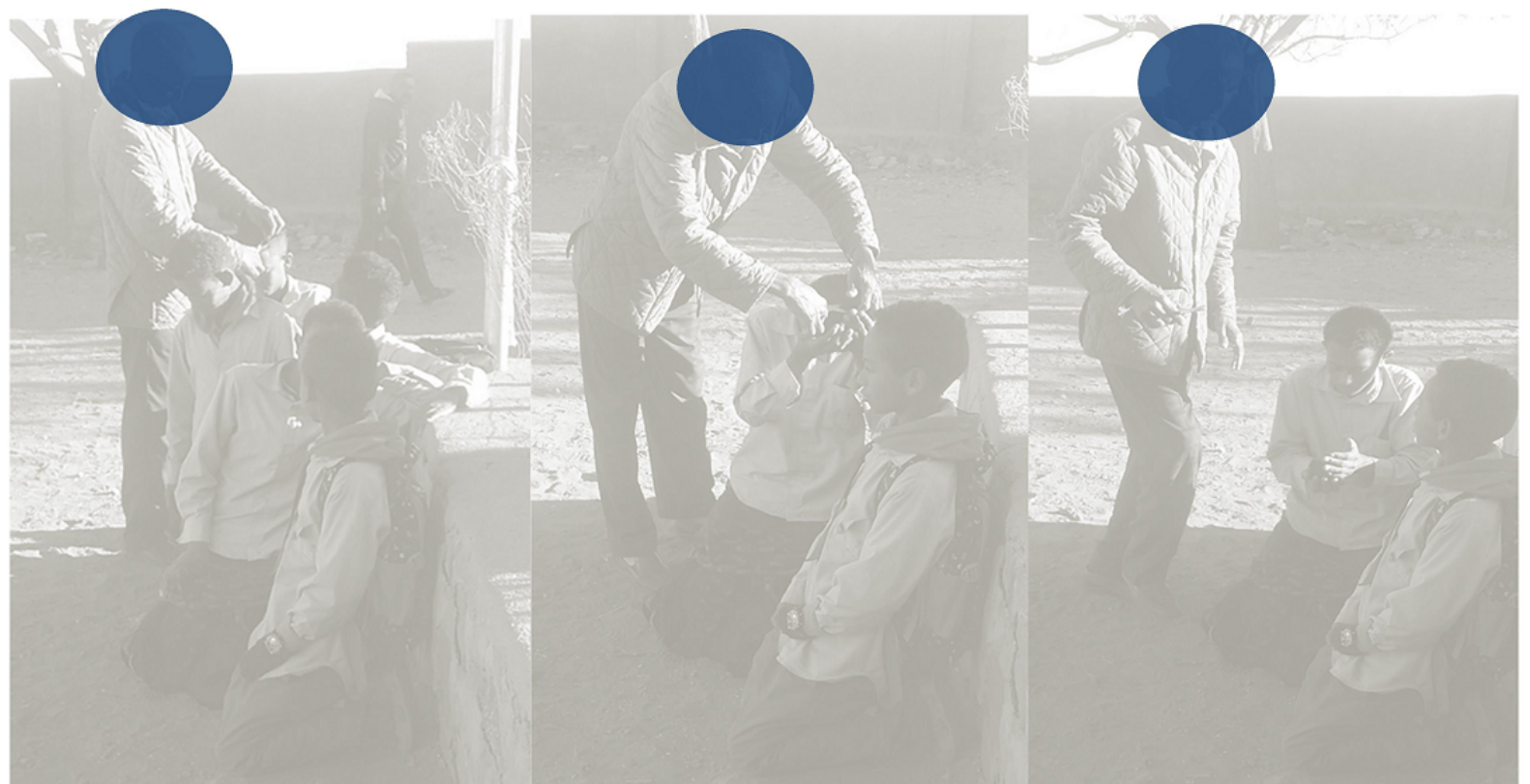

Forcing male students to kneel down to get their hair cut is another major technique that the school authorities apply often to humiliate the students. The intention of the haircut is to deface the hairstyle of the students and to threaten them. The students are expected to obediently follow the orders. The above series of pictures show that a member of the school management team called the students while entering the school. Every student is told to kneel down and obediently wait for their turn to get awful haircut. Those who got the haircut by force humbly receive the trash in their open palms as observed in the last series of the pictures. From the researchers' point of view, the students were every elegant with respect to their hair style in the school.

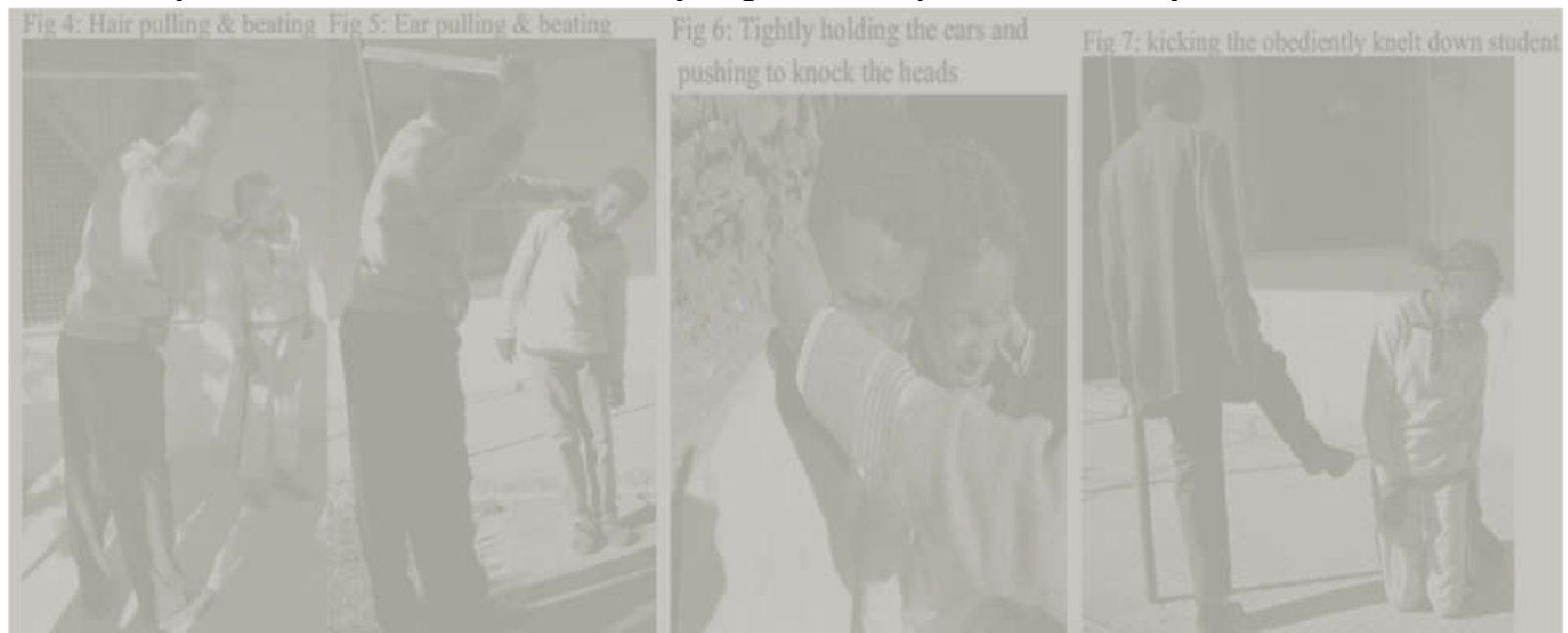

Source: Graduating students senior paper, Asmara College of Education (2019)

The above figures clearly show the diversity of the types of corporal punishments used by teachers and school leaders to treat misbehaving students. Teachers use all sorts of corporal punishments, stick is always at hand. The school based photos endorse "every picture tells a story." All the series of photos above show that every incident represents a combination of at least two types of punishments. A little girl is being pulled from the hair and bitten by the stick (Fig 4), a male student is being pulled from the ear and bitten by the stick (Fig 5), the 
teacher is tightly holding and pulling the two students from the ear to collide them by the head (Fig 6), a student hopelessly knelt down and the punisher is kicking her (Fig 7).

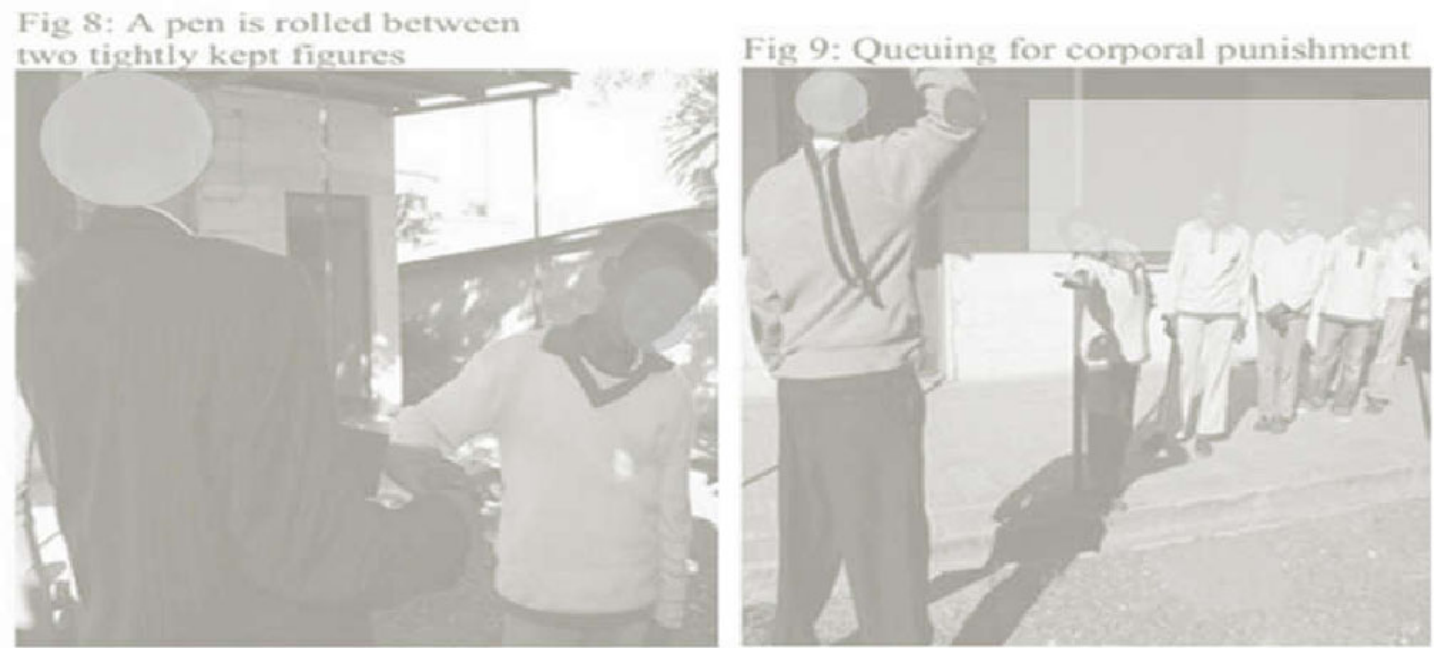

Source: Graduating students senior paper, Asmara College of Education (2019)

Fig. 8 presents a teacher punishing a student by tightly holding a pen between his fingers and the student is helplessly feeling the painful experience. On Fig 9, a group of students are observed humbly waiting for their turn to offer their palms for the inevitable corporal punishment and the teacher furiously whipping their palms using a whip.

\section{Discussions}

The United Nations banned all sorts of intentional violence against human beings in its Universal Declaration of Human Rights of 1948 and the United Nations' Convention on the Rights of the Child (CRC) (1989). However, researches indicate both developed and developing counties still practice harsh treatments of students disciplining that compromise the physical and psychological wellbeing of children (Save the Children Swaziland, December 2008). In 2016, the number of countries that signed the banning of corporal punishment in schools reached 69, including Eritrea (Global Initiative, 2016). The Proclamation No.1/1991 of the Transitional Penal Code of Eritrea (TPCE) "officially rejects corporal punishment and flogging as inhumane kinds of punishment" (The State of Eritrea, Periodic National Report, 2015, p.187). The TPCE strictly bans corporal punishment in any institution including families and schools. A working document of the MoE entitled 'Avoiding Corporal Punishment in Eritrean Schools' prepared in 2010 was developed to increase the teachers' and school leaders' awareness towards the adverse effects of corporal punishment. The document clarifies "corporal punishment violates human rights, physical integrity and human dignity" (ibid, p. 190). It is prepared in accordance with the national policy and international conventions about the right and the protection of children from all forms of violence. Therefore, by principle, schools in Eritrea are not allowed to use corporal punishment to discipline misbehaving students. This empowers teachers, school management team and other staff members to avoid physical violence and to develop and use relevant knowledge, skills and strategies of disciplining techniques in their classes and the school compound.

However, in the Eritrean school system, the major role of the management team, especially the leaders in charge of the student affairs and the pedagogy heads in schools are over involved in the nitty-gritty of disciplining the students' within the classrooms and the school compound. The leaders in a school, especially the person in charge of the office of student affairs in a school is active in surveillance of students' behavioral aspects and hairstyle in the school compound. When a critical observer reads the interaction between person in charge of the students' affairs and students in schools, one can observe paradoxical events. The office of the student affairs is often full of students knelt down for punishment or confiscated school bags of students who would need further actions. School teachers and leadership use varieties of disciplining techniques in response to students' misbehaviors in the school compounds. Teachers usually use a stick to punish students by beating on the hand and sometimes serious hitting on other parts of the body, slapping on the face, tweaking the ear, knocking the head, etc. (see the figures above). Teachers are blamed by students for punishing the whole class, especially when they fail to pinpoint the particular student(s) suspected as misbehaving. Teachers use corporal punishment, collective sit ups, walking while kneeling or sitting, kneeling in the sunny place, temporary expulsion of students from the class, verbal and written warnings by signing in the presence of a parent/guardian.

Students who damage school properties or who fail to respect some school instructions are penalized financially. Although fines may not contribute as an effort of shaping the misbehavior of students, the logic is that the students have to take responsibility for their misbehaviors. But this is not that much concern for the 
young students, because their families shoulder the burden of paying the fine. The schools try to handle misbehaving students by discomforting the misbehaving student using different techniques including forced labor in the school compound, cutting their hair on the spot in a haphazard way, deducting marks, making fun of the misbehaving student to discourage the misbehavior by humiliating the student in front of his/her classmates. Some teachers take photo of a student while misbehaving and show to the parents and the discipline committee of the school as exhibit.

The school management teams often temporarily confiscate misbehaving students' belongings, including the learning materials till the students call a parent/guardian. Especially, when students are found using smart phones or any other devices for watching videos, playing games, etc., the properties of students are held in the office for further consultation. However, many of the undesirable disciplinary techniques used by teachers and principals often remain under-reported by teachers than students (Mumthas, Munavvir and Abdul, 2014). Teachers also send away disturbing students from class, reprimand, beat and refer to the headmaster's office, etc. However, the findings of the current study revealed that majority of the disciplining techniques are corporal punishments that reflect the teachers' and principals' aggression rather than wisely guiding and disciplining the students to change the misbehaviors. The common disciplinary practices of teachers and principals are highly reactionary and punitive rather than proactive and constructive disciplinary approaches.

In the African school system, teachers and principals often use corporal punishment in and outside classrooms (Kambuga, Manyengo \& Mbalamula, 2018). Ineffective teachers rush to use threats and punishments whenever they attempt to discipline students (Walters \& Frei, 2007). Unfortunately, disciplining children through corporal punishment within the institutions of families and schools "remains a socially accepted and legal issue in many countries" regardless of their state of development (Save the Children - Swaziland, December 2008, p. 6). Culture plays a great role in orchestrating the disciplining procedures practiced in schools (Lopes and Oliveira, 2017). Corporal punishment for youngsters at school and at home is socially accepted in the Eritrean society. Corporal or physical punishment is a common disciplining technique of misbehaving students in schools. It is very much common from elementary to secondary school that teachers go to class holding a stick with the teaching materials. If one makes a sudden visit to any school in Eritrea, she/he will hardly find a teacher entering class without a stick or whip on the hand to "discipline" students inside and outside class. Even the school guards sit at the gate holding a stick either to block them late comers from entering classrooms or hold back those who want to dismiss classes before the school day ends.

Gyan et al. (2015) noted that student failing to do homework, coming late to school, bringing cell phones to school, running in the hallway, sleeping in class, answering questions incorrectly, having an unacceptable appearance, using bad language, writing in a text book, failing to pay school fees, making noise in class, and being absent are subjected to corporal punishment in Ghanaian secondary schools. Late comers are always punished in the school compound in a number of ways, including missing classes, crawling on the knee and clearing the school compound. Teachers and principals in schools (in Tanzania) use corporal punishment "on minor discipline problems such as late coming, classroom noise, not respecting teachers or prefects and not wearing school uniforms" (Kambuga, Manyengo, and Mbalamula, 2018, p. 185). When students commit serious disgrace, the school decides an academic suspension for the student in response to the misbehaviors.

\section{Alternative disciplinary mechanisms to positively impact misbehaving students}

The way the school teachers and the principals attempt to discipline misbehaving students determine the nature of the elicited behaviors of the students. Teachers and school leaders are punishing rather than disciplining the misbehaving students in schools. The schools are curious about controlling trivial issues such as the hairstyle and other external factors and do little impact to positively change the mindset and thinking of students. Therefore, disciplinary techniques used by the school principals and teachers while dealing with misbehaving students have very little to do with correction mechanisms. According to Mumthas, Munavvir and Abdul (2014), teachers often use undesirable disciplinary techniques "more than constructive disciplinary practices" (p. 301). Effective and caring teachers face less behavioral problems by students compared to teachers perceived as ineffective teachers who use punitive strategies (Rahimi \& Karkami, 2015). Teachers, principals and other school leaders practice corporal punishment as way of venting their anger rather than disciplining misbehaving students. Teachers and principals use the punitive strategies as a result of their stressful and frustrating experiences at school (ibid).

Schools are full of diversities of students' backgrounds and needs that make every student unique and require empathic understanding. Schleicher (2018) in his classic book noted that "educators try to look at every child individually" (p.16). Thus, schools can sustainably maintain desirable behaviors of students by promoting their intrinsic motivation and reinforcement (Ormrod, 2000). Teachers and school principal that recognize and understand students' challenges and employ adaptive strategies, positive reinforcement and rewarding are perceived as effective. Providing students opportunities for practical learning, consistent and explicit verbal instructions, unconditional approach and empathic understanding of students problems foster the possibility of positively reshaping misbehaving students (ibid). 
Participants suggested positive disciplining alternative techniques to the currently handing of misbehaving students in the schools need careful attention. The schools should focus on building healthy relationship between teachers and students, guiding misbehaving students to consult school counselors, campaigning to instill vision and positive change in the mindset of the learners. Teachers and school leaders need to develop tolerance to minor disciplining problems of students and working in collaboration with stakeholders in schools to cultivate the students' good characters. The findings revealed that there is a need of amending the current school curriculum and improving teaching methodology to positively influence students' behaviors and enhance learning engagement of students. Ineffective teaching approaches reinforce students' lack of learning engagement and encourage them to misbehave. Therefore, according to the participants, the current curriculum needs modification and alignment to practicality to enhance students' engagement and minimize classroom discipline problems.

The State of Eritrea (Periodic National Report, 2015) indicated that the TPCE publicly proclaimed all government and non-government institution are strictly required to stop corporal punishment and use positive alternative forms of disciplining. In a research conducted by (Sadik, 2017) a student participant noted that in schools "discipline is like glass, if you hold it too tight, it breaks" (p. 34). The participant further pointed out that using pressure and control to discipline misbehaving student does not necessarily produce desirable behavior. Schools require alternative school based positive disciplining techniques to deal with students' misbehaviors. Therefore, teachers and school principals are required to employ adaptive approaches in disciplining misbehaving students (Kambuga, Manyengo and Mbalamula, 2018). Teachers and leaders in the school environment need to exemplify "disciplined behavior" and morality so that their students emulate them (Ukala, 2018). Positive techniques of shaping and modifying learners' undesirable behaviors productively are likely to increase students' classroom performance and academic achievements and decrease problem behaviors of the students (Ormrod, 2000).

Creating conducive learning environment in schools is a crucial initiative that significantly determines the desirable learning behavior of learners. In rare cases, schools transfer misbehaving students to other schools with assumption to change the student's behavior by changing the human and physical school environment. School environment that supports the students' wellbeing fosters the learners' academic achievement and their future oriented goals in life (Lyu, et al., 2017). On the contrary, when the environment promotes negative affect of students, the phenomenon promotes aggressive behavior and confrontations. This in turn negatively affects the students' academic achievement and even their intention to stay in school.

The disciplining techniques of time out/taking away something the learner values, response cost (withdrawal of positive factors) related to negative reinforcement and the positive reinforcement techniques are rare in the Eritrean schools. The findings of the study with respect to the positive disciplining alternative techniques teachers and school managers use boil down to positive reinforcement mechanism through reward and encouraging approaches such as awarding prizes for "well behaving" students at the end of an academic year merely for the "acceptable" behaviors. Teachers and school leaders can positively influence misbehaving students through powerful positive empowering words and minimizing insults and irritating words that lead to confrontations. Mumthas, Munavvir and Abdul (2014) found that "teachers give priority to counselling, loving, caring, entrusting responsibility and friendship" while students prioritize "counseling and modeling" (p. 307) as alternative practices to student disciplining practices in school environment.

Students come to school with great diversity of background, attitude, interest and capabilities. Knowing the students' background, teachers should tell and show their unconditional love to their students and accept them as they are. Teachers are expected to punish the misbehavior not the student. Thus, teachers should care and love their students unconditionally without discrimination. However, meeting students' needs and managing their behaviors require skill and care. The schools need to enhance teachers' skills of managing emotions, empathic listening and good communication skill that are helpful in understanding the reasons behind the misbehavior and the use of effective positive techniques to discipline students.

Students complain for being punished by teachers and school administrators without any requests of clarifications from students and proper explanations from the punisher. Teachers are required to develop their listening skills for smooth teaching and learning process. Healthy student-teacher relationship is essential to embolden the learning bond among students. Building healthy relationship with the students by empathic listening and understanding them before rushing to punishment was one of the major strategies recommended by participants. Teachers and school leaders can positively influence the behavior of the misbehaving students when they use some positive disciplining techniques such as regulating students' behaviors by changing the sitting arrangement of a misbehaving student in class. Effective teachers establish good rapport with students and personally advise them. Teachers are aware of the role of guidance and counseling in schools because referring misbehaving students to see a counselor in the school was the most frequently mentioned by the participants to deal with problem behaviors of students. This positive intervention would give a chance for the misbehaving students to develop self-understanding and constructively work with their problem behaviors. However, there is 
lack of functional guidance and counseling services in the schools (Andegiorgis, 2019). A teacher respondent said that "usually teachers refer misbehaving students to the principal's office."

Therefore, schools need highly trained counselors, resources and conducive environment to provide support services to students and orient the teachers accordingly. In addition, schools need to intensify awakening campaigns to enhance the future orientations and broaden personal visions of students and to increase students' awareness about the unwanted behaviors and their consequences in life. It is commonsense that if students are not treated humanely, they become hopeless in life, let alone in school. This would help teachers and school managers to avoid criticizing students and put efforts to make the students better citizens. Schools are required to put effort to develop teachers' wisdom and tolerance to professionally deal with teenagers. Especially in classrooms, teachers are expected to control their emotions and patiently ignore minor incidents of students' misbehaviors (Galand, Lecocq and Philippot, 2007).

The major positive aspect of Eritrean school system in disciplining misbehaving students is the fact that schools highly emphasize on the involvement of parents in their children's learning. The parent-teacher association is well established in the structure of the policy and the practices of the school system. However, teachers indicate that currently the parental involvement is not satisfactory. In the Eritrean school system, it is common practice in schools to inform students to call their parents/guardians for consultation with teachers. But students do not want their parents know about their case and often deceive teachers by brining any person from the street to dramatize the parental consultation. Gyan, et al. (2015) highlighted the fact that the home-school partnership has been overemphasized and strongly recommend for schools to strengthen the link. Therefore, strengthening the triangular cooperative relationship between parents, students and teachers would enhance managing misbehaving students and over all smooth teaching and learning process in schools. Another strong point raised about the MoE is that the schools proactively conduct sporadic campaign programs in collaboration with stakeholders such as the police department to raise the moral of students and to minimize incidents of serious misbehavior by students.

However, teachers insist that corporal punishment would still be helpful to the schools in managing students' misbehaviors. According to Makhasane and Chikoko (2016), teachers complain that the act of banning corporal punishment in schools has "disempowered" them. Teachers claim that it is their "right to practice corporal punishment" (Save the Children-Swaziland, December 2008, p.5). Similarly, an academically successful secondary school student in Eritrea posed a question saying that "if you are trying to stop the corporal punishment teachers practice, then how do you expect the teachers to deal with the students and teach them?" Thus, using corporal punishment is still seen as the right option for disciplining students in the schools in Eritrea. Furthermore, this notion is deeply embedded in the society that people believe strict and punishing schools produce best students.

In conclusion, the disciplinary techniques used by teachers and school leaders in disciplining misbehaving students are usually corporal punishment with very little chance of positive alternative strategies. There is a need to increase students' learning motivation, to avoid corporal punishment of students and instead to use positive strategies of reshaping undesirable behaviors of students in the schools. Research findings show that as part of parental involvement package, schools have to intensify the triangular relationship of parents, school and students to nurture desired behaviors. The MoE should have up-to-date and inclusive nationwide working rules and regulation about student disciplines and ensure their regular practice. Motivating and encouraging teachers to be committed in cultivating disciplined students in line with the societal core values should be in the priority list of the MoE. As curriculum is dynamic, the national curriculum requires revision and alignment to the teaching strategies in practice to engage students in learning.

\section{Reference}

Andegiorgis, G. E. (2019). Status of counselling services in secondary schools in Keren sub zone, Anseba Region, Eritrea. Global Journal of Guidance and Counseling in Schools: Current Perspectives, 9(1), 048055.

Asmara College of Education, Department of Psychology (2019). Students' misbehaviors and teachers' disciplining techniques in Asmara Secondary Schools (Senior Essay Project).

Ekamen, E. E., \& Edet, O. A. (2013). Efffects of corporal punisment on disciplinary control of secondary school studentsin Calbar Methropolis of Naigeria. Global Journal of Educational Research, 12, 19-25.

Galand, B., Lecocq, C. and Philippot, P. (2007). School violence and teacher professional disengagement. British Journal of Educational Psychology, 77, p. 465-477.

Global Initiative to End All Corporal Punishment of Children. Global progress towards prohibiting all corporal punishment. $2016 \mathrm{~g} \quad$ Retrieved from: http://endcorporalpunishment.org/assets/pdfs/legalitytables/Global\%20progress\%20table\%20with\%20terrs $\% 20 \% 28$ alphabetical\%29.pdf.

Gyan, E. et al. (2015). Teachers' and students' perceptions of discipline and wow often acts of indiscipline occur 
in Ghanaian secondary schools: Case Study of a Secondary School in Sunyani. American Research Journal of Humanities and Social Sciences, 1(3), p. 1-7.

Kambuga, Y. M., Manyengo, P. R., \& Mbalamula, Y. S. (2018). Corporal Punishment as a Strategic Reprimand used by Teachers to curb Students' Misbehaviours in Secondary Schools: Tanzanian Case. International Journal of Education and Research, 6(4), 1830-194.

Llywodraeth Cymru, Welsh Government (2012). Practical approaches to behavior management in the classroom: A handbook for classroom teachers in primary schools. Retrieved from www.cymru.gov.uk.

Lopes, J., \& Oliveira, C. (2017). Classroom discipline: Theory and practice. In J. P. Bakken (Ed.), Classrooms: Academic content and behavior strategy instruction for students with and without disabilities (Vol. 2, pp. 231-253). New York: Nova Science Publishers.

Lyu, B. et al. (2017). Relationship among children's social-emotional comptence, social support, academic achievement and aggressive behavior in the in the elementary schools of China. Journal of Educational Psychology, 8 (23), p. 29-39.

Marciniak, A. (2015). Effective ways of dealing with discipline problems when teaching adolescent learners. The World Scientific News, 7, 53-72.

Makhasane, S. D. and Chikoko, V. (2016). Corporal punishment contestations, paradoxes and implications for school leadership: A case study of two South African high schools. South African Journal of Education, 36(4), p. 1-8.

MoE (September 1997). Rules and regulations of students' discipline [in Eritrean schools) (Working document).

Mumthas, N. S., Munavvir, J., \& Abdul, G. K. (2014). Student and teacher perception of disciplinary practices: Types, reasons, consequences and alteratives. 2(4), 301-308.

Ormrod, J. E. (2000). Educational psychology: Developing learners (3rd ed.). New Jersey: Prentice-Hall Inc.

Rahimi, M. and Karkami, F. H. (2015). The role of teachers' classroom discipline in their teaching effectiveness and students' language learning motivation and achievement: A path method. Iranian Journal of Language Teaching Research 3(1), 57-82.

Sadik, F. (2017). Childeren and discipline: Investigating secondary school students' perception of discipline through metaphors. European Journal of Educational Research, 7(1), 31-45.

Save the Children - Swaziland (December 2008). Prevalence of Corporal Punishment and other forms of Humiliating Punishment on Children in Swaziland.

Schleicher, A. (2018). World Class: How to build a 21 st century school system, strong performers and successful reformers in education. Paris: OECD Publishing.

Sunday-Piaro, M. (2018). Classroom management and students' academic performance in public secondary schools in Rivers State. International Journal of Scientific Research in Education, 11(5), 940-963.

The State of Eritrea (Consolidated, $1^{\text {st }}, 2^{\text {nd }}, 3^{\text {rd }}$ and $\left.4^{\text {th }}\right)(2015)$. Periodic National Reports on the Implementation of the African Charter on the Rights and Welfare of the Child (ACRWC).

Ukala, C. C. (2018). Students' perception of discipline in public secondary schools in Revers State, Nigeria. European Journal of Research in Social Sciences, 6(3). p. 35-50.

Walters, J., \& Frei, S. (2007). Managing classroom behavior and discipline. USA: Shell Education. 